\title{
Thialkalivibrio nitratireducens sp. nov., a nitrate-reducing member of an autotrophic denitrifying consortium from a soda lake
}

\author{
Correspondence \\ Dimitry Yu. Sorokin \\ soroc@inmi.da.ru
}

\author{
Dimitry Yu. Sorokin, ${ }^{1,2}$ Tat'yana P. Tourova, ${ }^{1}$ Klaas A. Sjollema ${ }^{3}$ \\ and J. Gijs Kuenen ${ }^{2}$ \\ ${ }^{1}$ Institute of Microbiology, Russian Academy of Sciences, Prospect 60-let Octyabrya 7/2, \\ 117811 Moscow, Russia \\ ${ }^{2}$ Kluyver Laboratory of Biotechnology, Delft Technical University, Julianalaan 67, 2628 BC \\ Delft, The Netherlands \\ ${ }^{3}$ Laboratory for Electron Microscopy, Biological Centre, University of Groningen, 9750 AA \\ Haren, The Netherlands
}

\begin{abstract}
Strain ALEN $2^{\top}$ was isolated from a mixed culture capable of complete autotrophic denitrification with thiosulfate as electron donor at $\mathrm{pH} 10$; the mixed culture was enriched from sediment from Lake Fazda (Wadi Natrun, Egypt), a hypersaline alkaline lake. The isolate had large, non-motile, coccoid or barrel-shaped cells with intracellular sulfur globules. The bacterium was obligately chemolithoautotrophic. It grew with reduced sulfur compounds aerobically and anaerobically with nitrate as electron acceptor, nitrate being reduced to nitrite. It was moderately halophilic and obligately alkaliphilic. On the basis of genetic analysis and its unique phenotype, strain ALEN $2^{\top}$ ( $=$ DSM $14787^{\top}=$ UNIQEM $213^{\top}$ ) is proposed as the type strain of a novel species of the genus Thialkalivibrio, Thialkalivibrio nitratireducens.
\end{abstract}

Only a few species of lithotrophic sulfur-oxidizing bacteria (SOB) are capable of anaerobic growth with sulfur compounds and nitrogen oxides as electron acceptors. In particular, obligately autotrophic Thiobacillus denitrificans, Thiomicrospira denitrificans and facultatively autotrophic Paracoccus species perform the complete denitrification of nitrate to nitrogen gas, whereas filamentous, vacuolated, SOB Beggiatoa and Thioploca species appear to conduct dissimilatory nitrate reduction to ammonia with sulfide as electron donor (Kuenen et al., 1992; McHatton et al., 1996; Otte et al., 1999). Such SOB play an important role in mineral cycling and waste removal by linking the sulfur and nitrogen cycles (Kuenen \& Robertson, 1987; Robertson \& Kuenen, 1992). Of the haloalkaliphilic SOB isolated from soda lakes, currently represented by nearly 100 isolates (Sorokin et al., 2000, 2001a, 2002a, 2002b), only one, described as Thialkalivibrio denitrificans $\mathrm{ALJD}^{\mathrm{T}}$, has the potential for anaerobic growth. This strain differs from its neutrophilic analogues Thiobacillus denitrificans and Thiomicrospira denitrificans in that it does not possess a dissimilatory nitrate reductase. It grows with nitrite or $\mathrm{N}_{2} \mathrm{O}$ as

Published online ahead of print on 21 March 2003 as DOI 10.1099/ ijs.0.02615-0.

Abbreviation: SOB, sulfur-oxidizing bacteria.

The GenBank accession number for the 16S rDNA sequence of Thialkalivibrio nitratireducens ALEN $2^{\top}$ is AY079010. electron acceptor and thiosulfate or polysulfide as electron donor (Sorokin et al., 2001b). Recently, an enrichment culture has been obtained from a sediment sample from an alkaline hypersaline lake in Wadi Natrun (Egypt) that completely reduced nitrate to nitrogen gas, with thiosulfate as electron donor, at $\mathrm{pH} 10$. In this report, the nitratereducing member of this haloalkaliphilic autotrophic denitrifying association is described.

Sediment from Lake Fazda, a hypersaline soda lake (250 g total salts $\left.1^{-1} ; \mathrm{pH} 10\right)$ in the Wadi Natrun (Egypt), was used as inoculum to enrich for denitrifying SOB. The basic hydrochemical and microbiological characteristics of the Wadi Natrun lakes have been described by Taher (1999) and Imhoff et al. (1979), respectively. The enrichment was performed in $100 \mathrm{ml}$ serum bottles with butyl-rubber stoppers filled with $50 \mathrm{ml}$ alkaline base containing $0.6 \mathrm{M}$ total $\mathrm{Na}^{+}$, pH 10 (Sorokin et al., 2001a), with $20 \mathrm{mM}$ thiosulfate and $30 \mathrm{mM}$ nitrate. Anoxic conditions were achieved by five cycles of evacuation-flushing with argon with active degassing of the liquid. Solid medium was prepared by $1: 1$ mixing of the above-mentioned alkaline base containing a double concentration of substrates and $4 \%(\mathrm{w} / \mathrm{v})$ agar at $50{ }^{\circ} \mathrm{C}$. Anaerobic plate incubation was performed using closed jars filled with pure argon in the presence of anaerobic catalyst (Oxoid). Growth with $\mathrm{H}_{2}$ as electron donor was tested in $100 \mathrm{ml}$ bottles closed with butyl-rubber stoppers containing $10 \mathrm{ml}$ medium under an 
atmosphere of $98 \%(\mathrm{v} / \mathrm{v}) \mathrm{H}_{2}$ and $2 \%(\mathrm{v} / \mathrm{v}) \mathrm{O}_{2}$. Methylotrophy was tested with methanol and formate $(5 \mathrm{mM})$ under aerobic and denitrifying conditions. The $\mathrm{pH}$ range for growth was tested on media prepared using $0 \cdot 1 \mathrm{M} \mathrm{HEPES/}$ $\mathrm{Na}_{2} \mathrm{CO}_{3}$ (pH 7-8) supplemented with $0.6 \mathrm{M} \mathrm{NaCl}$ or sodium carbonate/sodium bicarbonate $(\mathrm{pH} \mathrm{8-11)}$ with $0.6 \mathrm{M}$ total $\mathrm{Na}^{+}$. $\mathrm{Na}^{+}$tolerance was tested on sodium carbonate/bicarbonate-based mineral medium containing $0 \cdot 1-2 \cdot 0 \mathrm{M}$ total $\mathrm{Na}^{+}$at $\mathrm{pH} 10$. The same $\mathrm{pH}$ and salinity buffers were used in experiments with washed cells. Respiration activity, reduction of nitrogen oxides by washed cells, sulfur-metabolizing activity, denitrifying enzymes and cytochrome spectra were measured as described previously (Sorokin et al., 2002c). Inorganic sulfur compounds, nitrate, nitrite, $\mathrm{N}_{2} \mathrm{O}$ and protein concentrations were determined by spectrophotometric and GC methods as described previously (Sorokin et al., 2001a, b). DNA extraction, DNA $\mathrm{G}+\mathrm{C}$ content determination and DNA-DNA hybridization were performed according to standard protocols (Marmur, 1961; De Ley et al., 1970). For amplification and sequencing of the $16 \mathrm{~S}$ rRNA gene, DNA was obtained by standard phenol/chloroform extraction. The $16 \mathrm{~S}$ rRNA gene was selectively amplified using primers 5'-AGAGTTTGATCCTGGCTCAG-3' (forward) and 5' -TACGGTTACCTTGTTACGACTT-3' (reverse). PCR products were purified from low-melting-point agarose using the Wizard PCR-Prep kit (Promega) according to the manufacturer's instructions. Almost-complete sequencing (1420 nt) was performed using the Promega Silver Sequencing kit according to the manufacturer's instructions, but with minor modifications. Primary comparative analysis of the 16S rRNA gene sequence of strain ALEN $2^{\mathrm{T}}$ with database sequences was done using BLAST. On the basis of results of the BLAST search, the $16 \mathrm{~S}$ rRNA gene sequences of strain ALEN $2^{\mathrm{T}}$ and its closest relatives were aligned using CLUSTAL_X (Thompson et al., 1997). Regions that were not sequenced in one or more reference organisms were omitted from subsequent analyses. An unrooted phylogenetic tree based on 16S rRNA gene sequences of the studied bacteria was constructed by the neighbour-joining method available in the TREECON package (Van de Peer \& De Wachter, 1994). Bootstrap analysis (100 replications) was used to validate reproducibility of the branching pattern of the tree.

The anaerobic enrichment resulted in a stable binary culture consisting of large irregular coccoid cells with intracellular sulfur globules and thin straight rods that were occasionally motile. The latter were responsible for nitrite reduction. On the basis of their physiology and genetic properties, the thin straight rods resembled the previously described haloalkaliphilic SOB Thialkalivibrio denitrificans (Sorokin et al., 2001b). Further work focused on isolation and characterization of the unusual coccoid morphotype that was responsible for the reduction of nitrate to nitrite.

The coccoid organism was present in relatively low numbers in the mixed denitrifying culture, which made it difficult to isolate. When plated onto nitrate/thiosulfate alkaline agar under an argon atmosphere, a surprisingly low proportion of the total cells present in liquid culture produced colonies. It appeared that the numerically dominant small rods depended on the coccoid phenotype for growth, resulting in formation of mixed colonies. By picking up the colony material containing mostly the coccoid morphotype and replating it, the colony number of the desired organism gradually increased. Eventually, pure colonies of the coccoid phenotype were obtained, and the isolated bacterium was designated strain ALEN $2^{\mathrm{T}}$. It formed colonies of variable size and shape, 1-3 mm, some flat, some dome-like. The young colonies were shining white and full of sulfur, turning reddish and transparent with time. Cells in the colonies were extremely pleomorphic, mostly coccoid, with multiple intracellular sulfur globules. Cells grown aerobically on liquid medium with thiosulfate at $\mathrm{pH} 10$ were coccoid, $0 \cdot 8-2 \cdot 0 \mu \mathrm{m}$ in diameter and aggregated in chains of different lengths (Fig. 1a, c). The cells grown anaerobically in liquid culture were barrel-shaped and less aggregated (Fig. 1b, d).

The bacterium was obligately autotrophic. It grew well under fully aerobic conditions, oxidizing $40 \mathrm{mM}$ thiosulfate at $\mathrm{pH} 10$ within 3 days with prominent formation of intracellular sulfur $(8-10 \mathrm{mM})$, which was finally oxidized to sulfate within another 3-5 day period. Maximum specific growth rate with thiosulfate under aerobic conditions was $0 \cdot 08 \mathrm{~h}^{-1}$, with a yield of $5 \cdot 5-6 \cdot 0 \mathrm{mg}$ protein $\mathrm{mmol}^{-1}$. The bacterium belonged to the obligate alkaliphiles $(\mathrm{pH}$ range for growth of $8 \cdot 0-10 \cdot 5$, with optimum at $9 \cdot 5-10 \cdot 0)$ and moderate halophiles (salt range for growth of $0 \cdot 2-1 \cdot 5 \mathrm{M}$ total $\mathrm{Na}^{+}$, with an optimum at $0 \cdot 4-0 \cdot 5 \mathrm{M}$ ). Respiration activity of the washed cells with sulfide and thiosulfate was maximal at $\mathrm{pH} 10$ and still substantial at $\mathrm{pH} 11(20 \%$ from maximum; data not shown). Strain ALEN $2^{\mathrm{T}}$ actively oxidized sulfide and, at much lower rates, polysulfide and thiosulfate. The oxidation activity of elemental sulfur was an order of magnitude lower than that of thiosulfate (Table 1), which accounts for a heavy sulfur accumulation in cultures.

In static aerobic cultures with thiosulfate, strain ALEN $2^{\mathrm{T}}$ reduced up to $15 \mathrm{mM}$ nitrate to nitrite. Full aeration inhibited nitrite production. Under anaerobic conditions, the bacterium was able to grow with nitrate as electron acceptor and thiosulfate, sulfide and polysulfide $\left(2 \mathrm{mmol} \mathrm{l}^{-1}\right.$ portions, fed-batch supply for the latter two) as substrates. With $20 \mathrm{mM}$ thiosulfate/40 $\mathrm{mM}$ nitrate, rapid nitrite production and transient sulfur accumulation were observed. When all the nitrate was consumed, growth was arrested. Finally, $38 \mathrm{mM}$ nitrite was produced per $11 \mathrm{mM}$ thiosulfate oxidized to sulfate, which corresponds to a two-electron nitrate reduction to nitrite (assuming that approximately $10 \%$ electrons are used for $\mathrm{CO}_{2}$ reduction). No anaerobic growth was observed with either nitrite $(10 \mathrm{mM})$ or $\mathrm{N}_{2} \mathrm{O}$ as electron acceptors. The fed-batch growth with sulfide/ nitrate proceeded in two phases. At first, when nitrate was still present, each $2 \mathrm{mM}$ addition of sulfide was followed by cell growth, transient sulfur formation with its further 

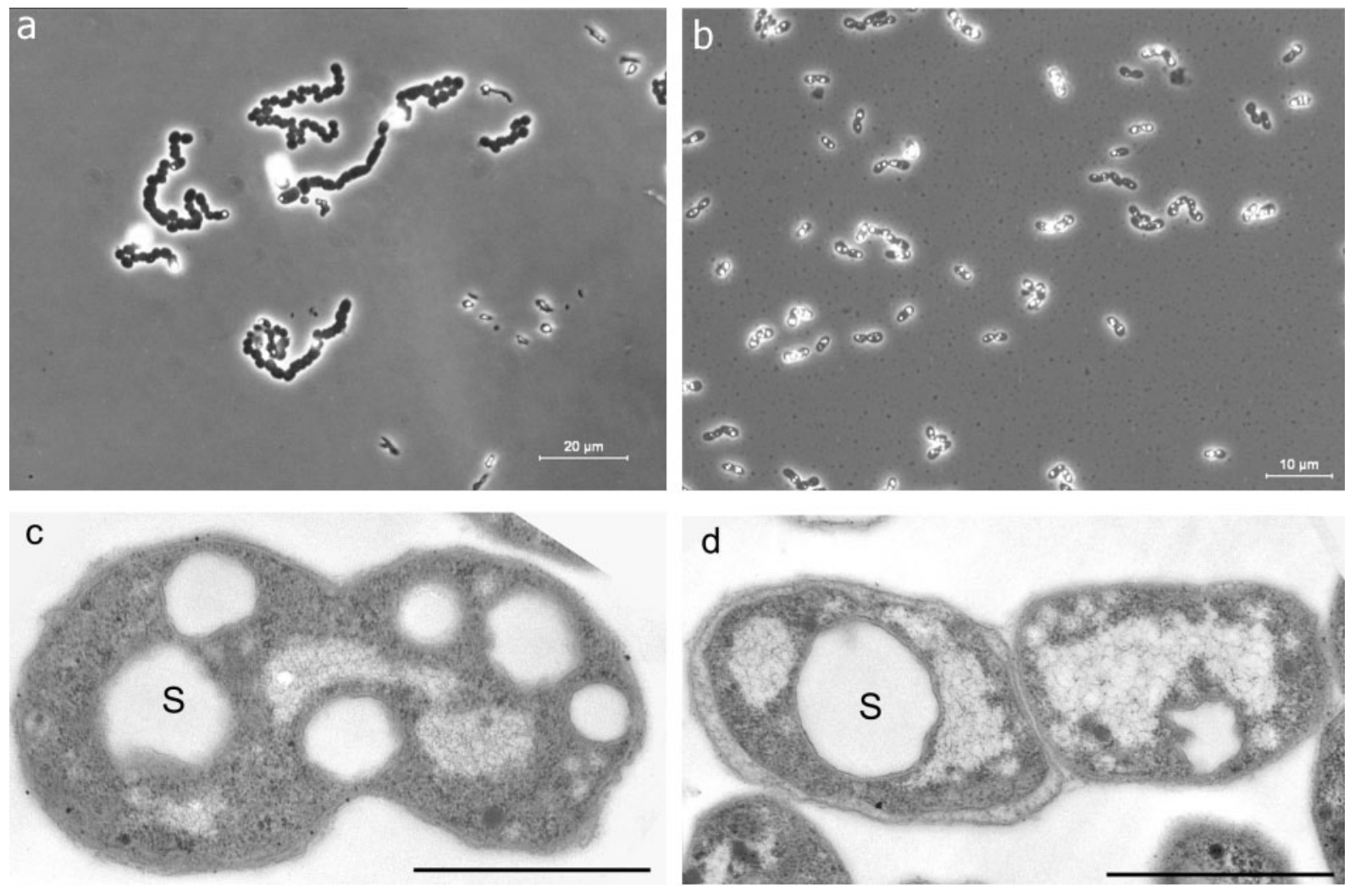

Fig. 1. Morphology of cells of strain ALEN $2^{\top}$ grown aerobically $(a, c)$ or anaerobically $(b, d)$ with thiosulfate at $p H 10$. (a) Phase-contrast; (b) phase-contrast; (c, d) thin section (bars, $1 \mu \mathrm{m}$ ). S, sulfur globules.

oxidation to sulfate and a build-up in nitrite concentration, similar to growth with thiosulfate. When nitrate was consumed, biomass increase stopped, but sulfide was still oxidized to elemental sulfur, accompanied by slow nitrite consumption with a molar $\mathrm{HS}^{-} / \mathrm{NO}_{2}^{-}$ratio of $2 \cdot 0-2 \cdot 5: 1$. The latter implies a one-electron reduction of nitrite to NO. Although $\mathrm{NO}$ was not measured, at this stage some $\mathrm{N}_{2} \mathrm{O}$ in the headspace was registered. However, no anaerobic

Table 1. Respiratory activity of washed cells of strain ALEN $2^{\top}$ grown aerobically at $\mathrm{pH} 10$ and $0.6 \mathrm{M} \mathrm{Na}^{+}$with thiosulfate

Results are the means from two experiments.

\begin{tabular}{|lcc|}
\hline $\begin{array}{l}\text { Substrate } \\
(\mathbf{5 0} \boldsymbol{\mu M})\end{array}$ & $\begin{array}{c}\text { Respiration rate }[\mathbf{n m o l} \\
\left.\mathbf{O}_{\mathbf{2}} \text { (mg protein }\right)^{-\mathbf{1}} \mathbf{~ m i n}^{\mathbf{- 1}} \text { ] }\end{array}$ & Products \\
\hline $\mathrm{HS}^{-}$ & 2810 & Sulfur \\
$\mathrm{S}_{\mathrm{n}}^{2-}$ & 430 & Sulfur \\
$\mathrm{S}_{8}$ & 32 & ND \\
$\mathrm{S}_{2} \mathrm{O}_{3}^{2-}$ & 175 & Sulfur + sulfate \\
$\mathrm{S}_{4} \mathrm{O}_{6}^{2-}$ & 38 & ND \\
$\mathrm{SO}_{3}^{2-}$ & 8 & Sulfate \\
\hline
\end{tabular}

ND, Not determined. growth was observed with sulfide and nitrite or $\mathrm{N}_{2} \mathrm{O}$ as electron acceptors. From these experiments, it was concluded that strain ALEN $2^{\mathrm{T}}$ is a high-capacity nitrateto-nitrite reducer and, therefore, may serve as a nitrite provider in a denitrifying association with a nitrite reducer. Further experiments with washed cells of strain ALEN $2^{\mathrm{T}}$ confirmed its inability to reduce nitrite and $\mathrm{N}_{2} \mathrm{O}$ with thiosulfate as electron donor. However, low nitrite-reducing activity was observed with polysulfide and $\mathrm{H}_{2}$ as electron donors (Table 2). In both cases, $\mathrm{N}_{2} \mathrm{O}$ was produced in the gas phase. Moreover, $\mathrm{H}_{2}$ also stimulated the reduction of elemental sulfur by washed cells of strain ALEN $2^{\mathrm{T}}$. Despite these facts, the bacterium was incapable of anaerobic growth with $\mathrm{H}_{2}$ as electron donor and nitrite or elemental sulfur as electron acceptors, which implies that some important links between the dissimilatory enzymes and the energy-generating system are missing in this unusual alkaliphilic SOB species.

In the soluble fraction of cell-free extract of strain ALEN $2^{\mathrm{T}}$, rapid nitrate-dependent oxidation of reduced methyl viologen was observed, but nitrite, the usual product of nitrate reductase activity, was not detected. Replacement of nitrate by nitrite in the reaction mixture resulted in extremely high rates of methyl viologen oxidation and nitrite consumption $\left[8 \cdot 0-10 \cdot 5 \mu \mathrm{mol} \mathrm{NO}-(\mathrm{mg} \text { protein })^{-1} \mathrm{~min}^{-1}\right]$. 
Table 2. Anaerobic activity of washed cells of strain ALEN $2^{\top}$

Cells were suspended in sodium carbonate/bicarbonate buffer containing $0.6 \mathrm{M} \mathrm{Na}^{+}, \mathrm{pH} 10$, at a protein concentration of $0 \cdot 3-0 \cdot 6 \mathrm{mg} \mathrm{ml}^{-1}$.

\begin{tabular}{|c|c|c|c|c|}
\hline \multicolumn{2}{|c|}{ Reaction } & \multicolumn{2}{|c|}{ Products of: } & \multirow{2}{*}{$\begin{array}{l}\text { Reduction rate }[\mathrm{nmol} \\
\left.(\mathrm{mg} \text { protein })^{-1} \mathrm{~min}^{-1}\right]^{*}\end{array}$} \\
\hline Donor & Acceptor & Oxidation & Reduction & \\
\hline \multirow[t]{3}{*}{$\mathrm{S}_{2} \mathrm{O}_{3}^{2-}$} & $\mathrm{NO}_{3}^{-}$ & $\mathrm{S}_{8}+\mathrm{SO}_{4}^{2-}$ & $\mathrm{NO}_{2}^{-}$ & $40-90$ \\
\hline & $\mathrm{NO}_{2}^{-}$ & - & - & $0-5$ \\
\hline & $\mathrm{N}_{2} \mathrm{O}$ & - & - & 0 \\
\hline \multirow[t]{3}{*}{$\mathrm{S}_{8}^{2-}$ (polysulfide) } & $\mathrm{NO}_{3}^{-}$ & $\mathrm{S}_{8}+\mathrm{SO}_{4}^{2-}$ & $\mathrm{NO}_{2}^{-}$ & $250-310$ \\
\hline & $\mathrm{NO}_{2}^{-}$ & $\mathrm{S}_{8}$ & $\mathrm{~N}_{2} \mathrm{O}$ & $30-40$ \\
\hline & $\mathrm{N}_{2} \mathrm{O}$ & - & - & 0 \\
\hline \multirow[t]{3}{*}{$\mathrm{H}_{2}$} & $\mathrm{NO}_{3}^{-}$ & - & $\mathrm{NO}_{2}^{-}$ & $9-11$ \\
\hline & $\mathrm{NO}_{2}^{-}$ & - & $\mathrm{N}_{2} \mathrm{O}$ & $7-10$ \\
\hline & $\mathrm{S}_{8}$ & - & $\mathrm{S}_{\mathrm{n}}^{2-}$ & $21-26$ \\
\hline
\end{tabular}

${ }^{\star}$ Rates of nitrite production or consumption during nitrate or nitrite reduction and sulfane atom production during sulfur reduction; endogenous rates without electron donors are subtracted.

This implies that strain ALEN $2^{\mathrm{T}}$ possesses both nitrate and nitrite reductase activities despite the fact that it is unable to use nitrite as an electron acceptor in vivo. Antipov et al. (2003) have demonstrated the presence of a nitrate/nitrite reductase in strain ALEN $2^{\mathrm{T}}$ with unusual properties. Activities of the sulfur-metabolizing enzymes thiosulfate reductase, sulfite dehydrogenase and sulfide dehydrogenase were found in the soluble fraction of cell-free extract of strain ALEN $2^{\mathrm{T}}$ at $\mathrm{pH} 10$ [690, 260 and $60 \mathrm{nmol}$ (mg protein $)^{-1} \min ^{-1}$, respectively]. The cell membranes of strain ALEN $2^{\mathrm{T}}$ contained high amounts of cytochrome types $c$ and $b$ (absorption maxima in the alpha region at 554 and $558 \mathrm{~nm}$, respectively). CO difference spectra of the membranes indicated the presence of a cytochrome oxidase of type $b b$ (troughs in alpha region at 558 and $563 \mathrm{~nm})$.

The $\mathrm{G}+\mathrm{C}$ content of the DNA of strain ALEN $2^{\mathrm{T}}$ was $64 \cdot 8 \pm$ $0.5 \mathrm{~mol} \%$. Phylogenetic analysis placed this bacterium in the genus Thialkalivibrio (Fig. 2), which accommodates the high-G $+\mathrm{C}$-containing species of haloalkaliphilic SOB (Sorokin et al., 2001a). The isolate had highest similarity $(98 \cdot 2 \%)$ to the thiocyanate-utilizing species Thialkalivibrio paradoxus (Sorokin et al., 2002b). Indeed, strain ALEN $2^{\mathrm{T}}$ resembled this species in its specific cell morphology and accumulation of intracellular sulfur due to a low elemental sulfur oxidizing capacity. These two strains also had the highest level of DNA-DNA relatedness (54\%) compared to values obtained with other species of Thialkalivibrio $(<30 \%)$. However, strain ALEN $2^{\mathrm{T}}$ was substantially different physiologically from Thialkalivibrio paradoxus: strain ALEN $2^{\mathrm{T}}$ was incapable of thiocyanate and carbon disulfide oxidation, whereas Thialkalivibrio paradoxus cannot utilize nitrate either as electron acceptor nor as nitrogen source. Overall, these differences suggest that strain ALEN $2^{\mathrm{T}}$ should be regarded as a novel species of the genus
Thialkalivibrio, for which the name Thialkalivibrio nitratireducens is proposed.

\section{Description of Thialkalivibrio nitratireducens sp. nov.}

Thialkalivibrio nitratireducens (ni.tra.ti.re.du'cens. N.L. n. nitras nitrate; L. part. adj. reducens converting to a different state; N.L. adj. nitratireducens reducing nitrate).

Cells are mostly coccoid or barrel-shaped, often in chains and aggregates, $0 \cdot 8-2 \cdot 0 \mu \mathrm{m}$ in diameter, often with large

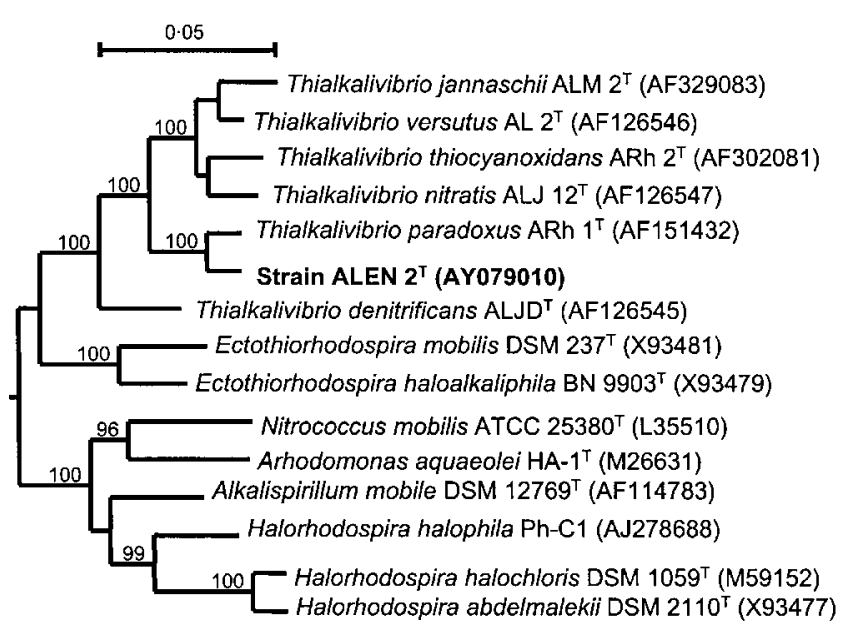

Fig. 2. Phylogenetic tree showing the position of the novel haloalkaliphilic strain ALEN $2^{\top}$ in the $\gamma$-Proteobacteria. Numbers on the branches refer to bootstrap values; only values above $90 \%$ are included. Bar, $5 \mathrm{nt}$ substitutions per $100 \mathrm{nt}$. Accession numbers are shown in parentheses. 
sulfur globules inside. Non-motile. Colonies are up to $3 \mathrm{~mm}$ in size, full of sulfur, turning reddish with age. Obligately chemolithoautotrophic. Oxidizes thiosulfate, sulfide, polysulfide and, much less actively, elemental sulfur and tetrathionate to sulfate. Facultatively anaerobic. Grows anaerobically with nitrate as electron acceptor and thiosulfate, sulfide or polysulfide as electron donor. The sole product of nitrate reduction is nitrite. Obligately alkaliphilic and moderately halophilic. Genetically most closely related to a thiocyanate-oxidizing species, Thialkalivibrio paradoxus.

The type strain is ALEN $2^{\mathrm{T}}$ (=DSM $14787^{\mathrm{T}}=\mathrm{UNIQEM}$ $213^{\mathrm{T}}$ ), isolated from sediments of Lake Fazda (Wadi Natrun, Egypt), a hypersaline soda lake. Its DNA G $+\mathrm{C}$ content is $64 \cdot 8 \pm 0 \cdot 5 \mathrm{~mol} \%$ ( $T_{\mathrm{m}}$ method). Other properties are as for the genus.

\section{Acknowledgements}

This work was supported by RFBR (grant 01-04-48782) and NATO (NB 83-193). We are grateful to M. Moussa for help in obtaining samples from the Wadi Natrun lakes and to B. Tindall for help in deposition of the bacterium in the DSMZ (Deutsche Sammlung von Mikroorganismen und Zellkulturen, Braunschweig, Germany).

\section{References}

Antipov, A. N., Sorokin, D. Y., L'Vov, N. P. \& Kuenen, J. G. (2003). New enzyme belonging to the family of molybdenum-free nitrate reductases. Biochem J 369, 185-189.

De Ley, J., Cattoir, H. \& Reynaerts, A. (1970). The quantitative measurement of DNA hybridization from renaturation rates. Eur J Biochem 12, 133-142.

Imhoff, J. F., Sahl, H. G., Soliman, G. S. H. \& Trüper, H. G. (1979). The Wadi Natrun: chemical composition and microbial mass developments in alkaline brines of eutrophic desert lakes. Geomicrobiol J 1, 219-234.

Kuenen, J. G. \& Robertson, L. A. (1987). Ecology of nitrification and denitrification. In The Nitrogen and Sulfur Cycles, pp. 162-218. Edited by J. A. Cole \& S. J. Ferguson. Cambridge: Cambridge University Press.

Kuenen, J. G., Robertson, L. A. \& Tuovinen, O. H. (1992). The genera Thiobacillus, Thiomicrospira and Thiosphaera. In The Prokaryotes, 2nd edn, pp. 2638-2657. Edited by A. Balows, H. G. Trüper, M. Dworkin, W. Harder \& K.-H. Schleifer. New York: Springer.

Marmur, J. (1961). A procedure for the isolation of deoxyribonucleic acid from microorganisms. J Mol Biol 3, 208-218.
McHatton, S. C., Barry, J. P., Jannasch, H. W. \& Nelson, D. C. (1996). High nitrate concentrations in vacuolate, autotrophic marine Beggiatoa spp. Appl Environ Microbiol 62, 954-958.

Otte, S., Kuenen, J. G., Nielsen, L. P. \& 7 other authors (1999). Nitrogen, carbon, and sulfur metabolism in natural Thioploca samples. Appl Environ Microbiol 65, 3148-3157.

Robertson, L. A. \& Kuenen, J. G. (1992). The use of natural bacterial populations for the treatment of sulfur-containing wastewater. Biodegradation 3, 239-254.

Sorokin, D. Y., Robertson, L. A. \& Kuenen, J. G. (2000). Isolation and characterisation of obligately chemolithoautotrophic alkaliphilic sulfur-oxidizing bacteria. Antonie van Leeuwenhoek 77, 251-260.

Sorokin, D. Yu., Lysenko, A. M., Mityushina, L. L., Tourova, T. P., Jones, B. E., Rainey, F. A., Robertson, L. A. \& Kuenen, J. G. (2001a). Thioalkalimicrobium aerophilum gen. nov., sp. nov. and Thioalkalimicrobium sibericum sp. nov., and Thioalkalivibrio versutus gen. nov., sp. nov., Thioalkalivibrio nitratis sp. nov. and Thioalkalivibrio denitrificans sp. nov., novel obligately alkaliphilic and obligately chemolithoautotrophic sulfur-oxidizing bacteria from soda lakes. Int J Syst Evol Microbiol 51, 565-580.

Sorokin, D. Yu., Kuenen, J. G. \& Jetten, M. S. (2001b). Denitrification at extremely high $\mathrm{pH}$ values by the alkaliphilic, obligately chemolithoautotrophic, sulfur-oxidizing bacterium Thioalkalivibrio denitrificans strain ALJD. Arch Microbiol 175, 94-101.

Sorokin, D. Yu., Gorlenko, V. M., Tourova, T. P., Tsapin, A. I., Nealson, K. H. \& Kuenen, G. J. (2002a). Thioalkalimicrobium cyclicum sp. nov. and Thioalkalivibrio jannaschii sp. nov., novel species of haloalkaliphilic, obligately chemolithoautotrophic sulfuroxidizing bacteria from hypersaline alkaline Mono Lake (California). Int J Syst Evol Microbiol 52, 913-920.

Sorokin, D. Yu., Tourova, T. P., Lysenko, A. M., Mityushina, L. L. \& Kuenen, J. G. (2002b). Thioalkalivibrio thiocyanoxidans sp. nov. and Thioalkalivibrio paradoxus sp. nov., novel alkaliphilic, obligately autotrophic, sulfur-oxidizing bacteria capable of growth on thiocyanate, from soda lakes. Int J Syst Evol Microbiol 52, 657-664.

Sorokin, D. Yu., Tourova, T. P., Kolganova, T. V., Sjollema, K. A. \& Kuenen, J. G. (2002c). Thioalkalispira microaerophila gen. nov., sp. nov., a novel lithoautotrophic, sulfur-oxidizing bacterium from a soda lake. Int J Syst Evol Microbiol 52, 2175-2182.

Taher, A. G. (1999). Inland saline lakes of Wadi El Natrun depression, Egypt. Int J Salt Lake Res 8, 149-170.

Thompson, J. D., Gibson, T. J., Plewniak, F., Jeanmougin, F. \& Higgins, D. G. (1997). The CLUSTAL_X windows interface: flexible strategies for multiple sequence alignment aided by quality analysis tools. Nucleic Acids Res 25, 4876-4882.

Van de Peer, Y. \& De Wachter, R. (1994). TREECON for Windows: a software package for the construction and drawing of evolutionary trees for the Microsoft Windows environment. Comput Appl Biosci 10, 569-570. 